\title{
Analgesic and Anti-inflammatory Properties of Argyreia Pilosa Wight \& Arn
}

\author{
Prasanth DSNBK ${ }^{1 *}$, Rao AS ${ }^{2}$ and Prasad $\mathrm{YR}^{3}$ \\ ${ }^{1}$ Research Scholar, Department of Pharmacy, JNTUK, Kakinada - 533 003, Andhra \\ Pradesh, India \\ 2Department of Pharmaceutical Analysis and Quality Control, Shri Vishnu College of
} Pharmacy, Bhimavaram, Andhra Pradesh, India

${ }^{3}$ Department of Pharmaceutical chemistry, University College of Pharmaceutical Sciences, Visakhapatnam, India

*Corresponding author: DSNBK Prasanth, Research Scholar, Department of Pharmacy, JNTUK, Kakinada-533 003, Andhra Pradesh, India, Tel: 7382027437; Email: dsnbkprasanth@gmail.com

\section{Abstract}

Background: Pain and inflammation are usually related to the pathophysiology of several medical conditions. The majority of antinociceptive and anti-inflammatory medications accessible within the merchandise found an outstretched purview of complications. The existing investigation was focused at identify the constituents and investigating the antinociceptive and anti-inflammatory activity of methanol extract of Argyreia pilosa whole plant.

Methods: The dried plant of $A$. pilosa was extracted with methanol and partitioned between Petroleum ether, chloroform, ethyl acetate, and butanol. The organic layer was fractionated by various stationary phases and identified by using spectral analysis. The methanolic extract was assessed for its antinociceptive activity by utilizing hot plate, tailimmersion and acetic acid induced writhing test, while anti-inflammatory activity has been established by Carrageenan induced paw edema carried out in vivo. The test group acquired two different doses of the extract (200 mg/kg and 400 $\mathrm{mg} / \mathrm{kg}$ ) orally. The positive control group acquired diclofenac ( $5 \mathrm{mg} / \mathrm{kg}$ ), tramadol ( $2 \mathrm{mg} / \mathrm{kg})$ orally. The negative control group acquired vehicle (2\% Tween $80,10 \mathrm{ml} / \mathrm{kg}$ ) orally. Additionally, preliminary phytochemical screening was performed.

Results: Phytochemical investigation of the whole plant of Argyreia pilosa (Convolvulaceae) afforded four known Phytoconstituents identified as Stigmasterol (1), ß-Sitosterol (2), Rutin (3) and Quercetin (4). The structures of those phytoconstituents have been elucidated based on spectral information analysis. Oral administration of $A$. pilosa methanol extract (at all doses) considerably $(\mathrm{p}<0.05)$ interdict pain sensitivity in the pain models. In the same manner, the extract exhibited anti-inflammatory activity in the inflammation models in the rat. Preliminary phytochemical screening showed the presence of flavonoids, alkaloids, tannins, phenols, steroids, fixed oils, fats, acid compounds, glycosides, amino acids, and proteins. 


\section{Open Access Journal of Pharmaceutical Research}

Conclusion: The outcome attained from the current investigation signifies that the extract owned a considerable antinociceptive and anti-inflammatory activity may be attributed to the presence of isolated constituents, indicating the traditional relevance of the plant and recommended to determine the other active chemical constituents accountable for the antinociceptive and anti-inflammatory activities.

Keywords: Argyreia Pilosa Wight \& Arn; Antinociceptive; Rutin; Stigmasterol; Anti-Inflammatory

\section{Introduction}

Even though the advancement made in the medical investigation in the elapsed few years, the management of certain severe disorders continuous to be problematic because of their complications and expensive cost related to it. Inflammation is a local response of animals towards injury. Generally, it is a body defense system to hinder the propagate of infection. It is concord with the formation of edema, leucocytes infiltration, and granuloma formation, tissue injury and repair [1]. Inflammation leads to activates inflammatory mediators such as TNF- $\alpha$, interleukins, and prostaglandins. Anti-inflammatory agents are able of suppressing the cyclooxygenase COX-1 and COX-2 pathway of arachidonic acid metabolism that generates prostaglandins [2]. Even though a large number of treatments are available in the market, such as immunosuppressants, NSAIDs, corticosteroids, and histamines, unwanted effects related with them restrict their usage. Osteoporosis, gastric lesions, high blood pressure, and allergy are the typical unwanted effects associated with them. Consequently, the focus has been aimed at the efficiency of plant-based medications with fewer side effects. In Accordance with WHO, 80\% of the world populace depend on plant-based remedies for primary healthcare. Approximately in 1997, the world marketplace over the counter phytopharmaceuticals had been US\$ 10 billion with a yearly growth of $6.5 \%$. WHO incorporates phytotherapy in its health programs as well as provides specific focus on the validation of drugs from plant origins in developing countries [3].

Pain is an unpleasant and emotional experience related to damaged tissue. Analgesics are the agents accustomed to reducing pain. Traditional analgesics of natural source such as opiates and NSAID drugs but they are associated with unwanted consequences like gastric lesions and tolerance and dependence. Therefore, there is ought to examine naturally available substitute resources to NSAIDs and opiates.

Secondary metabolites of plants like steroids, flavonoids, alkaloids, terpenoids, and glycosides have acquired significance because of their varied pharmacological activities like anti-inflammatory, analgesic and antipyretic, etc. Argyreia pilosa is an ornamental, in addition to a medicinal plant. All parts of this plant are widely used as a folklore medicine for the treatment of various ailments by the Indian traditional healer. Its root is utilized to cure a various illness like sexually transmitted diseases viz., gonorrhea and syphilis, blood diseases. Traditionally, the paste of the leaves is applied to the neck region for a cough, quinsy and applied externally in case of itch, eczema and other skin troubles, antidiabetic, antiphlogistic, rheumatism, reduce burning sensation and antidiabetic [4,5]. Young wines are mixed together with rhizome of ginger and spread all around the body to relieve from fever. The decoction of its root used to treat diarrhea and cathartic [6,7]. A vast range of phytochemical constituents has been separated from the genus Argyreia i.e., glycosides, alkaloids, amino acids, proteins, flavonoids, triterpene and steroids [8]. The genus Argyreia has been reported various biological activities including nootropic, aphrodisiac, antioxidant, antiulcer, immunomodulatory, hepatoprotective, antiinflammatory, antihyperglycaemic, antidiarrheal, antimicrobial, antiviral, nematicidal, anticonvulsant, analgesic, anti-inflammatory, wound healing and central nervous depressant activities [8-12]. Even though the drug has many uses, it's pharmacological and phytochemistry is very poorly explored. Therefore, the existing study was intended to identify and isolate the chemical compounds from the methanolic extract of $A$. pilosa. Whole plant for its antinoceceptive and antiinflammatory effects.

\section{Materials and Methods}

\section{Plant Material}

The plant material was obtained from Tirupati, Chittoor district of Andhra Pradesh, India during the month of March 2016 and authenticated by Dr. K. Madhava Chetty, Taxonomist, Sri Venkateswara University Tirupati, India. Voucher specimen No. 1922 was deposited at the herbarium of V. V. Institute of 


\section{Open Access Journal of Pharmaceutical Research}

Pharmaceutical Sciences, Gudlavalleru for future reference.

\section{Preparation of Extract}

The freshly collected plant was shade dried and pulverized. The powder $(1 \mathrm{Kg})$ was treated with petroleum ether for the removal of fatty and waxy material. Then it was air dried and macerated with methanol, filtered and concentrated at $45^{\circ} \mathrm{C}$ in Buchirotavapor. The weight of methanolic extract obtained was $75 \mathrm{~g}(7.5 \% \mathrm{w} / \mathrm{w}$ yield). The methanolic extract had been suspended in distilled water in a separating funnel and partitioned sequentially with petroleum ether, chloroform, ethyl acetate and n-butanol to acquire fractions in these solvents. Eventually, left residual aqueous fraction at the end was collected. The solvents were removed on a rotary evaporator at low pressure to obtain dried fractions. These extracts were subjected to preliminary phytochemical screening and these extracts were stored in the refrigerator at $4^{\circ} \mathrm{C}$ for further use [13].

\section{Phytochemical Screening}

The various extract of $A$. pilosa was subjected to qualitative chemical analysis by using standard procedures as follows.

The phytochemical screening of carbohydrates was detected by Molisch's test; Proteins were detected by using two tests namely Biuret test and millon's test and amino acids by Ninhyrdin test; Steroids was detected by Salkowski, Libermann- Burchard and Libermann's test; Alkaloids was identified with freshly prepared Dragendroff's Mayer's, Hager's and Wagner's reagents and observed for the presence of turbidity or precipitation. The flavonoids were detected using four tests namely Shinoda, sulfuric acid, aluminuim chloride, lead acetate, and sodium hydroxides. Tannins were detected with four tests namely gelatin, lead acetate, potassium dichromate and ferric chloride. The froth, emulsion, and lead acetate tests were applied for the detection of saponins. The steroids were detected by (acetic anhydride with sulfuric acid) and (acetic chloride with sulfuric acid) tests. Sample extracted with chloroform was treated with sulfuric acid to test for the presence of terpenoids. Ammonia solution and ferric chloride solutions were used to the presence of anthraquinone [14-17].

\section{Isolation of Constituents}

Petroleum ether extract (PEE) was subjected to silicagel (100-200 mesh) column (length $100 \mathrm{~cm}$ and diameter
$3 \mathrm{~cm}$ ) chromatography (elution rate of $2 \mathrm{ml} \mathrm{min-1} \mathrm{flow}$ with a total elution of $200 \mathrm{ml}$ ) and eluted with Petroleum ether and ethyl acetate in different proportions. The consequent fractions ( $\mathrm{Fr}$ ) were collected and spotted over pre-coated silica gel F254 plates $(20 \times 20 \mathrm{~cm}$, Merck, Germany). The optimum resolution was achieved with chloroform and ethyl acetate (5: $5 \mathrm{v} / \mathrm{v}$ ) solvent system and the plates were sprayed with anisaldehyde-sulphuric acid reagent to visualize the spots. The chloroform fraction was subjected to chromatography on silica gel (60-120 mesh, Merck) eluted with chloroform: ethyl acetate (5:5) solvent system. Repeated chromatography to give major two steroids i.e., PC-1 ( $\beta$-Sitosterol) and PC2 (Stigmasterol) [18]. After extraction, the aqueous layer was collected and left to stand in a cold place for 72 hours; a yellow precipitate separated out of the solution. The precipitate was filtered and washed with a mixture of chloroform: ethylacetate: ethanol (50:25:25). The undissolved part of the precipitate was dissolved in hot methanol and filtered, the filtrate was evaporated to dryness to give $115 \mathrm{mg}$ yellow powder i.e, PC-3 (rutin), and its melting point was measured [19]. The Ethyl acetate fraction was chromatographed using flash column on a Silica gel eluted with chloroform-methanol stepgradient (starting with 100:0 to 4:1), eluted fractions were combined on their TLC pattern to yield 8 fractions. The chloroform-methanol fraction (10:1) was chromatographed on a Sephadex LH-20 column eluted with chloroform-methanol (1:1) to yield PC-4 (Quercetin) [20].

\section{Experimental Animals}

The study was carried out on Wistar albino rats (160200g) of either sex (Mahaveer Enterprises, Hyderabad.) and was kept at an animal house in V. V. Institute of Pharmaceutical Sciences, Gudlavalleru bearing CPCSEA registration number 1847/PO/Re/S/16/CPCSEA. They were allowed to take standard pellet food and water $a d$ libitum. Before the experiment, the rats were kept in standard environmental conditions at room temperature $25-27^{\circ} \mathrm{C}$ relative humidity $(55 \pm 5) \%$ and $12 \mathrm{~h} \mathrm{light} / 12 \mathrm{~h}$ dark cycle for 7 days. All rats received humane care in accordance with the "Guide for the Care and Use of Laboratory Animals" [21].

\section{Acute Toxicity Study}

To evaluate the toxicity of $A$. pilosa extract the acute toxicity study was performed based on OECD (Organization for Economic Cooperation and Development) 423 guidelines up to the dose of 2000 $\mathrm{mg} / \mathrm{Kg}$. The rats were observed for $1 \mathrm{~h}$ continuously and then hourly for $4 \mathrm{~h}$ and finally after every $24 \mathrm{~h}$ up to 14 


\section{Open Access Journal of Pharmaceutical Research}

days for any physical signs of toxicity, such as writhing, gasping, palpitation and decreased respiratory rate or mortality. No animals died. Therefore the LD50 is greater than $2000 \mathrm{mg} / \mathrm{kg}$. Pre-screening investigation with 200 and $400 \mathrm{mg}$ per body weight was done [21].

\section{Antinociceptive Activity}

The antinociceptive activity of methanolic extract of root was evaluated by using three models: (1) Hot plate method based on pain sensation at $55^{\circ} \mathrm{C}$ (2) Tail Immersion and (3) Acetic Acid Induced Writhing method

Hot Plate Method: Central analgesic activity was evaluated using the hot plate method. The analgesic activity of methanolic extracts of the root and isolated constituents were evaluated in the rat by the method given by Eddy and Leimback [22]. This method was specifically used to evaluate the central action of both the methanolic extract and isolated constituents. The rats were divided into four groups comprising five animals each. Group, I received the only vehicle and served as control. Group II received tramadol $(2 \mathrm{mg} / \mathrm{kg}$ b.wt, i.p.) and served as standard. Groups III and IV were administered with methanolic extract of whole plant of $A$. pilosa in different doses of 200 and $400 \mathrm{mg} / \mathrm{kg}$ b.wt, i.p. respectively. Each rat was placed on the hot plate maintained at $55 \pm 2^{\circ} \mathrm{C}$, and the response time was recorded as the time at which animals reacted to pain stimulus by either paw licking response or jumping response, whichever appeared first at 15, 30, 45, 60 and 90 min after treatment.

The following calculation was

$\%$ analgesic activity $=\left(\mathrm{T}_{\mathrm{a}}-\mathrm{T}_{\mathrm{b}} / \mathrm{T}_{\mathrm{b}}\right) \times 100$

$\mathrm{T}_{\mathrm{a}}=$ Average of reaction time after the administration of extract

$\mathrm{T}_{\mathrm{b}}=$ Average of Initial reaction time

Tail Immersion Method: Tail immersion test was performed by immersing extreme $3 \mathrm{~cm}$ of the albino mouse tail in a hot water at a temperature of $55 \pm 0.5^{\circ} \mathrm{C}$. Within few second each mouse was reacted by withdrawing the tail, and the reaction time was recorded with a stopwatch. The drugs were given orally to the respective groups. The experiment was repeated at 0,30 , $60 \mathrm{~m} 90$ and $120 \mathrm{~min}$ following the administration of extracts and the standard drug [23].

Acetic Acid Induced Writhing Method: The antinoceceptive action of the extracts was assesses employing acetic acid induced writhing method in mice. In this approach, acetic acid was given intraperitoneally to the mice to produce pain sensation. As a positive control, any standard NSAID drug may be utilized. In the current investigation, diclofenac sodium utilized to assist the purpose. About 200 and $400 \mathrm{mg} / \mathrm{kg}$ bodyweight of the plant extract had been given orally to the Swiss albino mice after an overnight fast. Test samples as well as vehicle have been given orally $30 \mathrm{~min}$ just before to intraperitoneal administration of $0.7 \% \mathrm{v} / \mathrm{v}$ acetic acid solution $(0.1 \mathrm{~mL} / 10 \mathrm{~g})$ however diclofenac sodium has been given $15 \mathrm{~min}$ ahead to acetic acid injection. Then the animals were subjected an observation table. Each mouse of all groups was noticed separately for counting the number of writhing they produced in $15 \mathrm{~min}$ beginning merely $5 \mathrm{~min}$ as soon as the intraperitoneal administration of acetic acid solution. Full writhing was not usually achieved by the animal due to the fact occasionally the animals began to give writhing however they failed to complete it. This rudimentary writhing was regarded as half-writhing. Consequently, two halfwrithing had been considered as one full writhing. The number of writhes in every treated group was in comparison with control group while diclofenac sodium $(5 \mathrm{mg} / \mathrm{kg}$ ) utilized as a reference substance (positive control). The percentage inhibition was calculated using the formula described below

$\%$ Inhibition $=$ Mean no. of writhes (Control) - Mean no. of writhes (Treated) X 100

Mean no. of writhes control

\section{Anti-inflammatory Activity}

Carrageenan-Induced Paw Edema in Rats: All the animals were fasted overnight before the commencement of the experiment and only water was permitted ad libitum. A mark has been done on the tibiotarsal junction in the right hind foot of the rat so that every time the foot was dipped to a fixed volume. Acute inflammation was created in all the groups through administering $1 \% \mathrm{w} / \mathrm{v}$, $0.1 \mathrm{~mL}$ Carrageenan in normal saline into the sub-plantar tissue of the right hind foot, and the linear paw circumference was observed at $1 \mathrm{~h}, 2 \mathrm{~h}$ and $3 \mathrm{~h}$ by volume displaced by foot using Plethysmometer (IITC, Life Science, USA). Extracts and standard had been given intraperitoneally, $1 \mathrm{~h}$ prior to the administration of Carrageenan. The average increase in paw volume of each group was calculated and compared with the control group and the standard group [24]. Percentage inhibition of paw edema was calculated using the following formula $\%$ Inhibition $=\left\{1-\left[\left(\mathrm{V}_{\mathrm{d}}-\mathrm{V}_{\mathrm{p}}\right) /\left(\mathrm{V}_{\mathrm{c}}-\mathrm{V}_{\mathrm{p}}\right)\right]\right\} \times 100$

$V_{d}-V_{p}=$ Difference in paw volume after Carrageenan injection $\left(V_{d}\right)$ and before Carrageenan injection $\left(V_{p}\right)$ in Drug-treated group

$\mathrm{V}_{\mathrm{c}}-\mathrm{V}_{\mathrm{p}}=$ Difference in paw volume after Carrageenan injection $\left(\mathrm{V}_{\mathrm{c}}\right)$ and before Carrageenan injection $\left(\mathrm{V}_{\mathrm{p}}\right)$ in Vehicle-treated group 


\section{Open Access Journal of Pharmaceutical Research}

\section{Statistical Analysis}

Statistical analysis was carried out using Graph Pad Prism 5.0 (Graph Pad Software, San Diego, CA). All results were expressed as mean \pm SD. The data were analyzed by one-way ANOVA followed by Tukey multiple comparison tests.

\section{Results}

\section{Acute Toxicity Studies}

The methanolic extract of $A$. pilosa was proved to be

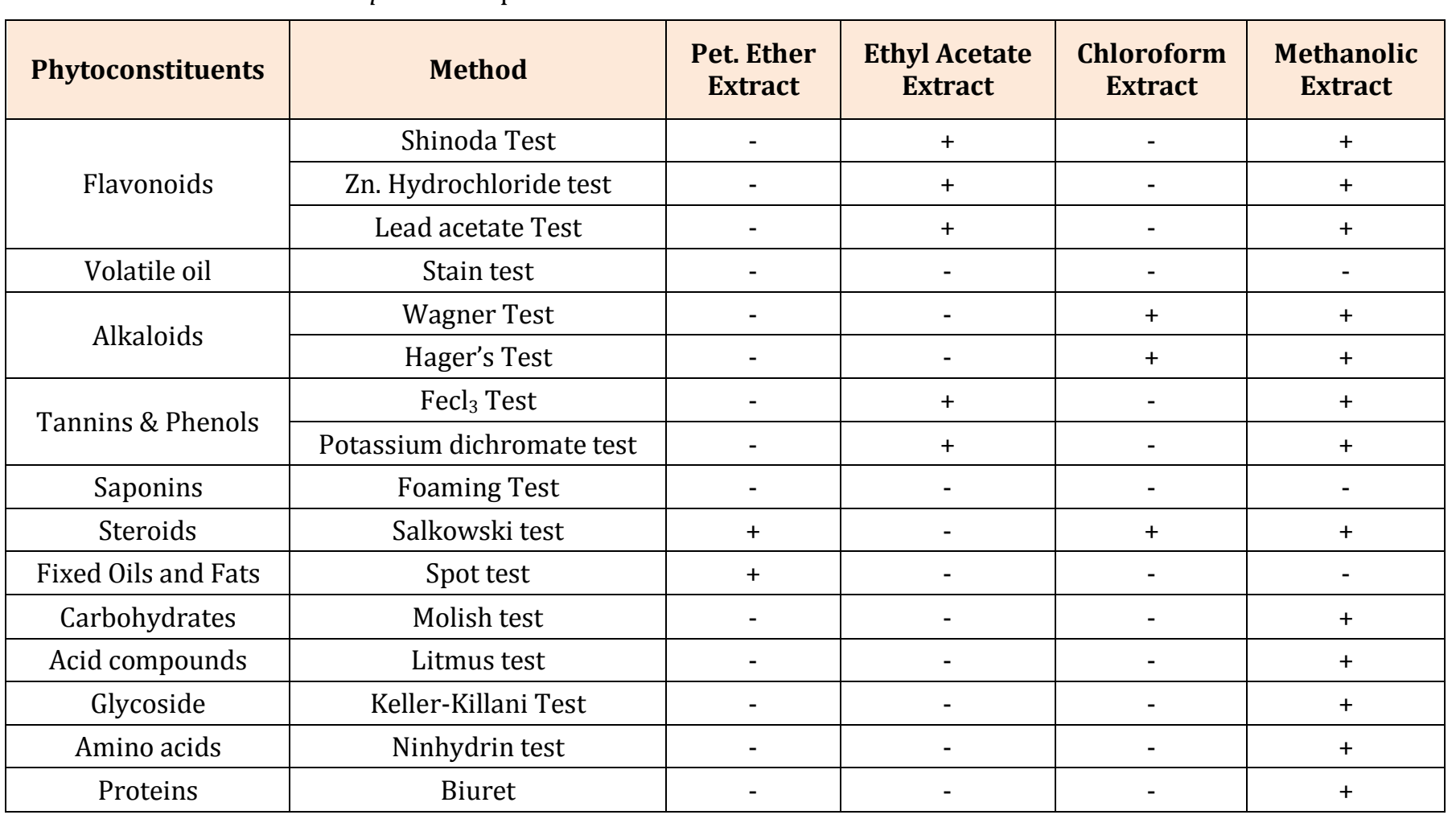

Table 1: Preliminary phytochemical screening of various extracts of Argyreia pilosa.

\section{Characterization of isolated Phytoconstituents}

Stigmasterol: White powder, $\mathrm{C}_{29} \mathrm{H}_{48} \mathrm{O}$, MW 412.69. UV $\lambda_{\max }\left(\mathrm{CHCl}_{3}\right) \mathrm{nm}: 257$; IR (KBr) $v_{\max } 3418(-\mathrm{OH}), 2934$, 2866, 2339, 1602, 1566, 1461, 1409, 1383, 1251, 1191, 1154, 1109, 1089, 1053, 1020, $791 \mathrm{~cm}^{-1}$; ESMS m/z (\%): 409.2, 395.3, 335, 161, 144, 121.1, 105.1, 97.1, 85.1, 69, $67.2,65,50.2 ;{ }^{1} \mathrm{H}$ NMR $\left(400 \mathrm{MHz}, \mathrm{CDCl}_{3}\right) \delta \mathrm{ppm}: 7.25(1 \mathrm{H}$, s, OH-2), 5.34-5.35 (1H, d), 5.12-5.18 $(1 \mathrm{H}, \mathrm{m}), 4.99-5.05$ $(1 \mathrm{H}, \mathrm{m}), 3.48-3.56(1 \mathrm{H}, \mathrm{m}), 2.18-2.31(2 \mathrm{H}, \mathrm{m}), 1.93-2.09$ $(3 \mathrm{H}, \mathrm{m}), 1.82-1.87(2 \mathrm{H}, \mathrm{m}), 1.66-1.75(1 \mathrm{H}, \mathrm{m}), 1.37-1.54$ $(13 \mathrm{H}, \mathrm{m}), 1.05-1.31(\mathrm{~m}, 7 \mathrm{H}), 0.99-1.01(\mathrm{~m}, 8 \mathrm{H}), 0.90-0.98$ $(\mathrm{m}, 2 \mathrm{H}), 0.78-0.85(\mathrm{~m}, 9 \mathrm{H}), 0.66-0.70(3 \mathrm{H}, \mathrm{t}) ;{ }^{13} \mathrm{C}$ NMR $\left(400 \mathrm{MHz}, \mathrm{CDCl}_{3}\right) \delta \mathrm{ppm}: 140.85(\mathrm{C}-4), 138.31$ (C-19), 129.40 (C-20), 121.72 (C-7), 77.34 (C-2), 71.86 (C-11), safe at $2000 \mathrm{mg} / \mathrm{kg}$ since even with this high dose no noticeable harmful or deleterious effects and fatality were noticed instantly or up to 14 days of the observation period. The outcome indicates that the extract possesses an $\mathrm{LD}_{50}$ of greater than $2000 \mathrm{mg} / \mathrm{kg}$.

\section{Phytochemical Screening}

The phytochemical screening for various extracts viz., petroleum ether, chloroform, ethyl acetate, methanol, nbutanol, and water was carried out and results were displayed in Table 1. 


\section{Open Access Journal of Pharmaceutical Research}

3.47-3.55 (1H, m), 2.19-2.31 (2H, m), 1.03-1.30 (9H, m), $1.00(4 \mathrm{H}, \mathrm{s}), 0.90-0.98(4 \mathrm{H}, \mathrm{m}), 0.76-0.86(9 \mathrm{H}, \mathrm{m}), 0.68-$ $0.69(3 \mathrm{H}, \mathrm{d}), 1.94-2.07(2 \mathrm{H}, \mathrm{m}), 1.79-1.88(4 \mathrm{H}, \mathrm{m}) ;{ }^{13} \mathrm{C}$ NMR (400 MHz, $\mathrm{CDCl}_{3}$ ) $\delta$ ppm: 140.84 (C-4), 121.70 (C-7), 71.82 (C-2), 56.94 (C-11), 56.85 (C-17), 50.25 (C-10), 45.95 (C-21), 42.39 (C-7), 42.36 (C-3), 39.87 (C-13), 37.34 (C-5), 36.57 (C-6), 36.19 (C-18), 33.78(C-19), 32.15 (C-8), 31.99 (C-9), 31.97 (C-7), 30.39 (C-22), 26.28 (C-20), 25.90 (C-15), 25.40 (C-16), 24.40 (C-24), 23.2 (C-23), 21.17 (C26), 21.06 (C-14) 21.06 (C-29), 19.32 (C-27), 19.34 (C-25), 12.11 (C-28). PC-02 was identified as $\beta$-Sitosterol.

Rutin: Yellow powder, $\mathrm{C}_{27} \mathrm{H}_{30} \mathrm{O}_{16}$, MW 610.52; UV $\lambda_{\max }$ (EtOH) nm: 203; IR (KBr) $v_{\max } 1001,1013,1065,1092$, $1150,1166,1203,1295,1362,1458,1504,1566,1601$, 1649, 2340, $3422 \mathrm{~cm}^{-1}$; ESMS m/z (\%): 609.1 (M-1); 610, 301; ${ }^{1} \mathrm{H}$ NMR (400 MHz, DMSO) $\delta$ ppm: $12.6(1 \mathrm{H}, \mathrm{s}), 10.84$ $(1 \mathrm{H}, \mathrm{s}), 9.68(1 \mathrm{H}, \mathrm{s}), 9.18(1 \mathrm{H}, \mathrm{s}), 7.55-7.56(1 \mathrm{H}, \mathrm{d}), 7.54$ $(1 \mathrm{H}, \mathrm{s})$ 6.84-6.86 $(1 \mathrm{H}, \mathrm{d}), 6.39(1 \mathrm{H}, \mathrm{d}), 6.2(1 \mathrm{H}, \mathrm{d}), 5.34-$ $5.36(1 \mathrm{H}, \mathrm{t}), 5.29(1 \mathrm{H}, \mathrm{d}), 5.11(1 \mathrm{H}, \mathrm{s}), 5.07-5.09(1 \mathrm{H}, \mathrm{d})$, $4.53(1 \mathrm{H}, \mathrm{s}), 4.39(2 \mathrm{H}, \mathrm{s}) .4 .35(1 \mathrm{H}, \mathrm{s}), 3.70-3.72(1 \mathrm{H}, \mathrm{d})$, 3.21-3.32 (1H, m), 3.05-3.10 (2H, t); ${ }^{13} \mathrm{C}$ NMR $(400 \mathrm{MHz}$, DMSO) $\delta$ ppm: 177.35 (C-4), 164.03 (C-7), 161.20 (C-5), 156.57 (C-8a), 156.40 (C-2), 148.37 (C-4'), 144.71 (C-5), 133.31 (C-3), 121.56 (C-1'), 121.18 (C-2'), 116.26 (C-3'), 115.21 (C-6'), 103.96 (C-6"'), 101.19 (C-6"), 100.70 (C4a), 98.65 (C-6), 93.55 (C-8), 76.46 (C-2"), 75.90 (C-4"), 74.06 (C-5"), 71.85 (C-2"'), 70.56 (C-5"'), 70.35 (C-3"'), 70.01 (C-4"'), 68.20 (C-3"), 66.97 (C-2a), 17.68 (C-2'"). PC03 was identified as Rutin.

Quercetin: Yellow powder, $\mathrm{C}_{15} \mathrm{H}_{10} \mathrm{O}_{7}$, MW 302.23; UV $\lambda_{\max }$ (EtOH) nm: 210; IR (KBr) $v_{\max } 3413,2340,1607,1565$, $1523,1462,1408,1383,1320,1263,1199,1168,1131$, 1014, 959, 782, 465, 457, 441, $423 \mathrm{~cm}^{-1}$; ESMS m/z (\%): 301 (M-H). 301.9, 300; ${ }^{1} \mathrm{H}$ NMR (400 MHz, DMSO) $\delta$ ppm:) $12.49(1 \mathrm{H}, \mathrm{s}), 10.77(1 \mathrm{H}, \mathrm{s}) .9 .57(1 \mathrm{H}, \mathrm{s}), 9.29-9.33$ $(2 \mathrm{H}, \mathrm{d}), 7.68-7.69(1 \mathrm{H}, \mathrm{d}), 7.53-7.69(1 \mathrm{H}, \mathrm{m}), 6.88-6.90$ $(1 \mathrm{H}, \mathrm{d}), 6.41(1 \mathrm{H}, \mathrm{d}), 6.19(1 \mathrm{H}, \mathrm{d}) ; 13 \mathrm{C}$ NMR $(400 \mathrm{MHz})$ 175.81 (C-7), 163.85 (C-1), 160.70 (C-3), 156.17 (C-5), 147.67 (C-9), 146.81 (C-15), 145.03 (C-8), 135.68 (C-11), 121.96 (C-12), 119.96 (C-13), 115.59 (C-16), 115.08 (C-4), 103.01 (C-2), 98.16 (C-6), 93.33. PC-04 was identified as Quercetin.

\section{Antinociceptive Activity}

Hot plate method: The results (mean \pm SEM) of hot plate showed that the crude methanolic extract (200 and 400 $\mathrm{mg} / \mathrm{Kg}$ ) exhibited an increase in basal reaction time from $8.7 \pm 0.458$ and $8.83 \pm 0.611$ at 0 min to $12.83 \pm 0.6$ and $14.13 \pm 0.6$ at $120 \mathrm{~min}$ respectively (Figure 1 , Table 2 ).

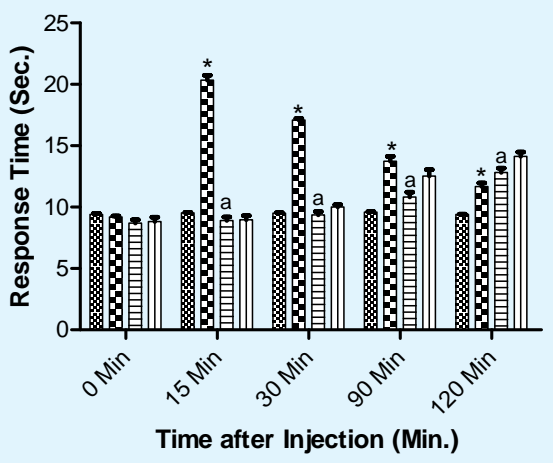

8\% Control E. Tramadol $(2 \mathrm{mg} / \mathrm{Kg})$ $\Longrightarrow \operatorname{MEAP}(200 \mathrm{mg} / \mathrm{Kg})$ एा) MEAP (400 mg/Kg)

Figure 1: Effect of Methanolic extracts of Argyreia pilosa on Hot-Plate Method. All the values are expressed as mean \pm SEM; $n=5$ mice in each group, by one way ANOVA followed by Tukey's Multiple Comparison Test. *, p $<0.01$ versus control; $\mathrm{a}, \mathrm{p}<0.01$ versus tramadol.

\begin{tabular}{|c|c|c|c|c|c|}
\hline \multirow{2}{*}{ Treatment } & \multicolumn{5}{|c|}{ Reaction Time (s) } \\
\cline { 2 - 6 } & $\mathbf{0}$ & $\mathbf{3 0}$ & $\mathbf{6 0}$ & $\mathbf{9 0}$ & $\mathbf{1 2 0}$ \\
\hline Control & $9.41 \pm 0.122$ & $9.53 \pm 0.085(1.27)$ & $9.50 \pm 0.083(0.95)$ & $9.59 \pm 0.058(1.91)$ & $9.48 \pm 0.040(0.74)$ \\
\hline Tramadol $(2 \mathrm{mg} / \mathrm{kg})$ & $9.2 \pm 0.15$ & $20.34 \pm 0.674^{*}(121.08)$ & $17.1 \pm 0.2^{*}(46.19)$ & $\begin{array}{c}13.73 \pm 0.680^{*} \\
(49.23)\end{array}$ & $11.67 \pm 0.526^{*}(26.8)$ \\
\hline MEAP $(200 \mathrm{mg} / \mathrm{Kg})$ & $8.7 \pm 0.458$ & $8.9 \pm 0.529^{\mathrm{a}}(2.29)$ & $9.36 \pm 0.472^{\mathrm{a}}(7.58)$ & $\begin{array}{c}10.83 \pm 0.65^{\mathrm{a}} \\
(24.48)\end{array}$ & $12.83 \pm 0.6^{\mathrm{a}}(47.47)$ \\
\hline MEAP $(400 \mathrm{mg} / \mathrm{Kg})$ & $8.83 \pm 0.611$ & $8.96 \pm 0.568(1.47)$ & $10 \pm 0.36(13.25)$ & $12.53 \pm 0.907(41.9)$ & $14.13 \pm 0.6(60.02)$ \\
\hline
\end{tabular}

All the values are expressed as mean \pm SEM; $n=5$ mice in each group, by one way ANOVA followed by Tukey's Multiple Comparison Test. ${ }^{* * *}, \mathrm{p}<0.001$ versus control; a, $\mathrm{p}<0.01$ versus tramadol.

Table 2: Effect of Methanolic extracts of Argyreia pilosa on Hot-Plate Method. 


\section{Open Access Journal of Pharmaceutical Research}

Tail Immersion Method: The tail immersion method revealed a well-marked increase in basal reaction time of $5.13 \pm 0.5$ in methanolic extract $(200 \mathrm{mg} / \mathrm{Kg})$ and $6.73 \pm$ 0.3 in methanolic extract $(400 \mathrm{mg} / \mathrm{Kg}$ ) at $120 \mathrm{~min}$ (Figure 2). The basal reaction time of control groups were $3.96 \pm$
0.47 and $4.43 \pm 0.47$ in tail immersion methods respectively (Table 3 ). The inhibition was the highest at $120 \mathrm{~min}$ at $400 \mathrm{mg} / \mathrm{kg}$ dose which was lower than standard.

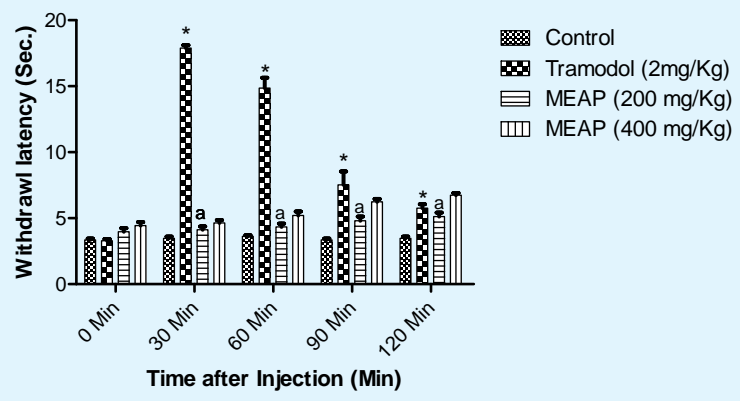

Figure 2: Effect of Methanolic extracts of Argyreia pilosa on Tail Immersion Method.

\begin{tabular}{|c|c|c|c|c|c|}
\hline \multirow{2}{*}{ Treatment } & \multicolumn{5}{|c|}{ Reaction Time (s) } \\
\cline { 2 - 6 } & \multicolumn{5}{|c|}{ Time after Treatment (min) } \\
\cline { 2 - 6 } & $\mathbf{0}$ & $\mathbf{3 0}$ & $\mathbf{6 0}$ & $\mathbf{9 0}$ & $\mathbf{1 2 0}$ \\
\hline Control & $3.35 \pm 0.162$ & $3.48 \pm 0.210$ & $3.63 \pm 0.127$ & $3.36 \pm 0.163$ & $3.47 \pm 0.220$ \\
\hline Tramadol $(2 \mathrm{mg} / \mathrm{kg})$ & $3.29 \pm 0.224^{*}$ & $17.9 \pm 0.36^{*}$ & $14.86 \pm 1.34^{*}$ & $7.55 \pm 1.738^{*}$ & $5.76 \pm 0.510^{*}$ \\
\hline MEAR $(200 \mathrm{mg} / \mathrm{Kg})$ & $3.96 \pm 0.47^{\mathrm{a}}$ & $4.13 \pm 0.416^{\mathrm{a}}$ & $4.33 \pm 0.45^{\mathrm{a}}$ & $4.8 \pm 0.55^{\mathrm{a}}$ & $5.13 \pm 0.5^{\mathrm{a}}$ \\
\hline MEAR $(400 \mathrm{mg} / \mathrm{Kg})$ & $4.43 \pm 0.47$ & $4.63 \pm 0.37$ & $5.2 \pm 0.51$ & $6.23 \pm 0.37$ & $6.73 \pm 0.3$ \\
\hline
\end{tabular}

All the values are expressed as mean \pm SEM; $n=5$ mice in each group, by one way ANOVA followed by Tukey's Multiple Comparison Test. Results are presented as mean \pm SEM, $(n=5)$, *, $p<0.05$ versus Control; a, $p<0.05$ versus Tramadol.

Table 3: Protective effect of Argyreia pilosa methanolic extract on tail withdrawal reflexes induced by tail immersion method in mice.

Acetic Acid Induced Wrighting: Control group showed maximum writhing $(24.4 \pm 1.140)$, while Methanolic extract of $A$. pilosa at a dose of 200 and $400 \mathrm{mg} / \mathrm{Kg}$ demonstrated a significant antinociceptive effect against

acetic acid induced writhing, inhibiting pain by $24.59 \%$ and $53.27 \%$ as compared to the control respectively (Table 4, Figure 3). Diclofenac at $5 \mathrm{mg} / \mathrm{kg}$ had $69.67 \%$ $(\mathrm{p}<0.001)$ inhibition of wrighting response.

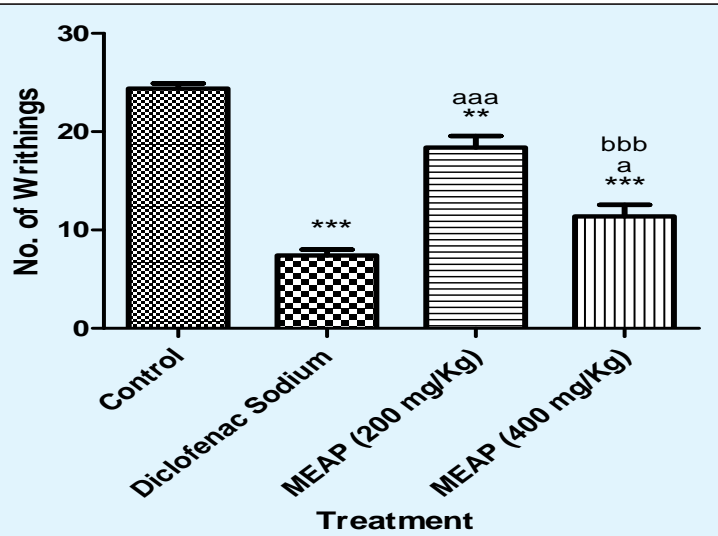

Figure 3: Effect of Methanolic extract of Argyreia pilosa on acetic acid induced Writhing in Mice. 
Open Access Journal of Pharmaceutical Research

\begin{tabular}{|c|c|c|c|c|c|c|c|c|}
\hline \multirow{2}{*}{ Treatment } & \multicolumn{5}{|c|}{ Writhing Count } & \multirow{2}{*}{$\begin{array}{c}\text { Writhings } \\
\text { (Mean } \pm \text { SEM) }\end{array}$} & \multirow{2}{*}{$\begin{array}{c}\text { \% of } \\
\text { Wrighting }\end{array}$} & \multirow{2}{*}{$\begin{array}{c}\% \text { of } \\
\text { Inhibition }\end{array}$} \\
\hline & M-1 & M-2 & M-3 & M-4 & M-5 & & & \\
\hline Control & 24 & 23 & 25 & 26 & 24 & $24.4 \pm 1.140$ & 100 & 0 \\
\hline Diclofenac Sodium & 6 & 9 & 8 & 8 & 6 & $7.4 \pm 1.341^{* * *}$ & 30.32 & 69.67 \\
\hline MEAP (200 mg/Kg) & 18 & 20 & 16 & 22 & 16 & $18.4 \pm 2.60^{* *}$, аaа & 75.4 & 24.59 \\
\hline MEAP (400 mg/Kg) & 12 & 12 & 10 & 15 & 8 & $11.4 \pm 2.60^{* * *}, \mathrm{a}, \mathrm{bbb}$ & 46.72 & 53.27 \\
\hline
\end{tabular}

Here, MEAP: methanolic crude extract of Argyreia pilosa. M-1= Mice 1, M-2 = Mice 2, M-3 = Mice 3, M-4 = Mice 4, M-5 = Mice 5.

Results are presented as mean \pm SEM, $(n=5),{ }^{* *}, \mathrm{p}<0.001$ versus Control, ${ }^{* *}, \mathrm{p}<0.01$ versus Control; aaa, $\mathrm{p}<0.001$ versus Diclofenac sodium; a, $\mathrm{p}<0.05$ versus Diclofenac Sodium and bbb, $\mathrm{p}<0.001$ versus MEAR $(200 \mathrm{mg} / \mathrm{Kg})$.

Table 4: Effect of Argyreia pilosa methanolic extract on acetic acid-induced writhing behavior in mice.

\section{Anti-inflammatory Activity}

Carrageenan-induced paw edema in rats: The results of the inhibitory effect of methanolic extracts on Carrageenan-induced rat paw edema are shown in Figure 4 and Table 5. The crude methanolic extract (200 and 400 $\mathrm{mg} / \mathrm{Kg}$ ) inhibited the edema volume of $21.97 \%$ and
$23.37 \%$ with a mean edema volume of $1.9 \pm 0.58$ and 1.58 \pm 0.22 at $3 \mathrm{~h}$ respectively. The Carrageenan control induced inflammation with a mean edema volume from $2.07 \pm 0.095$ at $0 \mathrm{~h}$ to $3.5 \pm 0.2$ at $3 \mathrm{~h}$. The standard drug (reference), diclofenac sodium showed inhibition of edema volume of $29.88 \%$.
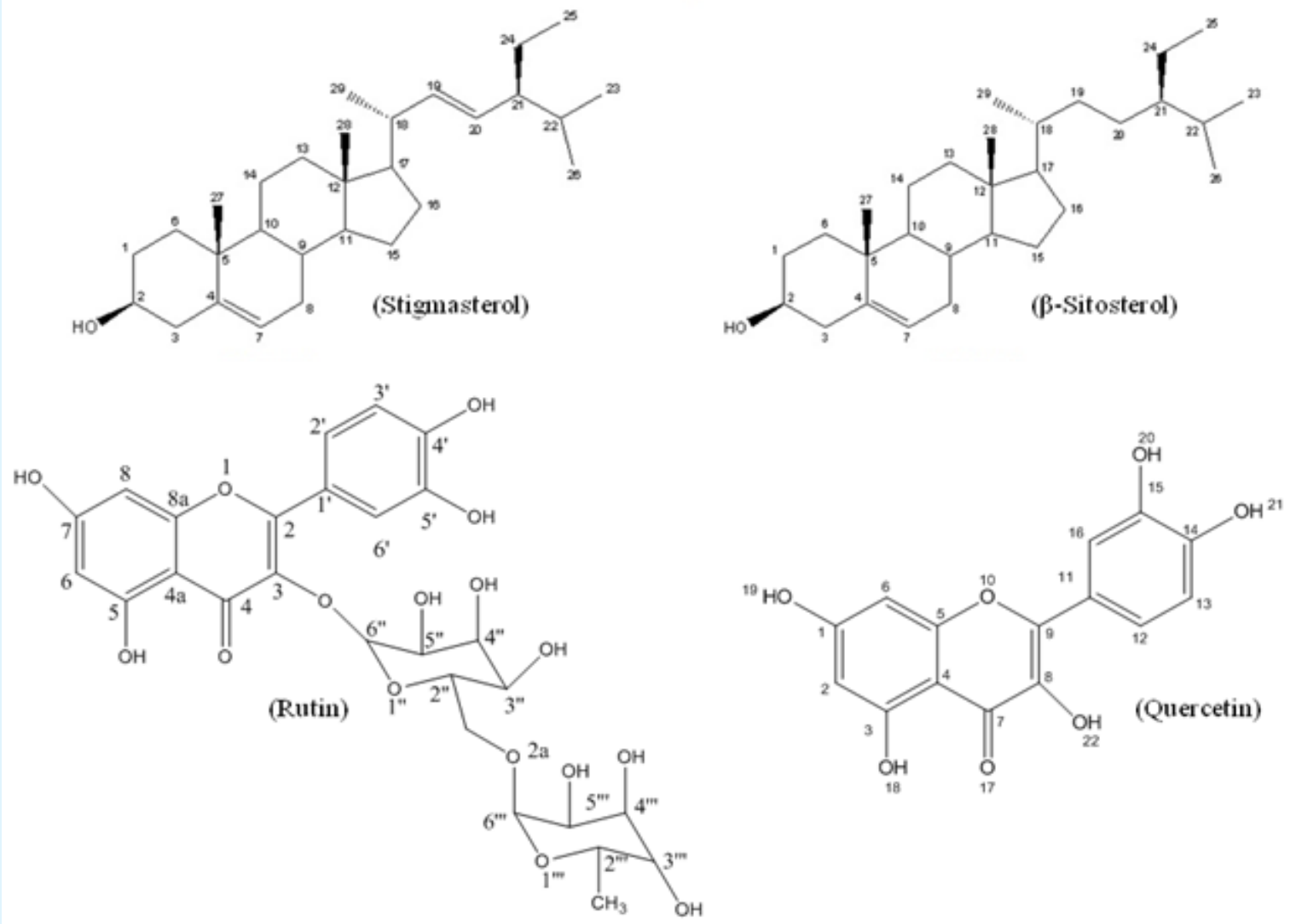

Figure 4: Chemical Compounds Isolated from A. pilosa plant extract with activity against Analgesic and Antiinflammatory. 


\section{Open Access Journal of Pharmaceutical Research}

\begin{tabular}{|c|c|c|c|c|c|c|c|}
\hline \multirow{2}{*}{ Group } & \multicolumn{3}{|c}{ Paw Volume at hrs (Mean \pm SD) } & \multicolumn{3}{c|}{ \% Inhibition at hrs } \\
\cline { 2 - 8 } & $\mathbf{0 ~ h r}$ & $\mathbf{1 ~ h r}$ & $\mathbf{2 ~ h r}$ & $\mathbf{3 ~ h r}$ & $\mathbf{1} \mathbf{~ h r}$ & $\mathbf{2} \mathbf{~ h r}$ & $\mathbf{3 ~ h r}$ \\
\hline Carrageenan $(1 \% 0.1 \mathrm{ml})$ & $2.07 \pm 0.095$ & $2.475 \pm 0.298$ & $2.95 \pm 0.3$ & $3.5 \pm 0.2$ & - & - & - \\
\hline $\begin{array}{c}\text { Carrageenan + } \\
\text { Diclofenac Sodium } \\
(5 \mathrm{mg} / \mathrm{Kg})\end{array}$ & $2.15 \pm 0.129$ & $2.075 \pm 0.095^{*}$ & $1.945 \pm 0.211^{*}$ & $1.737 \pm 0.106^{*}$ & 19.51 & 24.29 & 29.88 \\
\hline $\begin{array}{c}\text { Carrageenan + MEAP } \\
(200 \mathrm{mg} / \mathrm{Kg})\end{array}$ & $2.2 \pm 0.1^{\mathrm{a}}$ & $2.18 \pm 0.175^{\mathrm{a}}$ & $2.1 \pm 0.18^{\mathrm{a}}$ & $1.9 \pm 0.58^{\mathrm{a}}$ & 5.9 & 12.36 & 21.97 \\
\hline $\begin{array}{c}\text { Carrageenan + MEAP } \\
(400 \mathrm{mg} / \mathrm{Kg})\end{array}$ & $1.9 \pm 0.26$ & $1.85 \pm 0.33$ & $1.75 \pm 0.22$ & $1.58 \pm 0.22$ & 13.34 & 18.04 & 23.37 \\
\hline
\end{tabular}

Table 5: Effect of Methanolic extract of Argyreia pilosa on Carrageenan-Induced Paw edema method. Results are presented as mean \pm SEM, $(n=5),{ }^{*}, p<0.05$ versus Control and a, $\mathrm{p}<0.05$ versus Diclofenac Sodium.

\section{Discussion and Conclusion}

The safety of the herb had been affirmed by the acute toxicity study, carried out based on OECD test guidelines423 , which revealed that the plant extract at a higher dose of $2000 \mathrm{mg} / \mathrm{kg}$ developed no indication of toxicity or fatality in rat and mice.

It is hypothetic that alcoholic solvents effectively permeate cell membranes, enabling the extraction of formidable amounts of endocellular elements compared with lower polarity solvents including chloroform, which are constrained to extracting mainly extra-cellular material. In this way, alcohols dissolve primarily polar constituents along with moderate and lower polarity constituents. Therefore, methanol utilized as the solvent of preference in the current research for extracting the whole plant of $A$. pilosa [25].

In our Investigation, for those antinociceptive and antiinflammatory models, male rat and mice had been utilized. The primary reason for utilizing male sex regarding inflammation models is a result of the fact that estrogen exerts anti-inflammatory activity. In terms of pain, studies have demonstrated that variance in experimental pain reactivity is present in the various stages of the menstrual cycle in health females of reproductive age group. A meta-analysis about reports of experimental pain reactivity indicated females in the follicular stage possessed greater pain thresholds compared to later phases. Therefore, hormonal changing within the various stages of the menstrual cycle involving the female rat and mice might have an effect on pain reactivity. Consequently, to prevent this kind of distinction, male rat and mice were utilized $[26,27]$.

In the current investigation, we evaluated the effects of the crude methanolic extract of $A$. pilosa against the animal models to ascertain the anti-nociceptive and anti- inflammatory effects. The anti-nociceptive activity was assessed through acetic acid writhing in mice, hot plate, and tail immersion assays in the rat, whereas antiinflammatory activity had been carried out by Carrageenan-induced paw edema in rats.

The antinociceptive activity of the plant extract of $A$. pilosa was evaluated by using the hot plate, tailimmersion and acetic acid induced writhing methods. Hot Plate and Tail immersion tests are a central model. Tail immersion test provides discernment for opioid derived analgesics. The potency of agents in this particular model demonstrates antinociceptive activity through central mechanism acting via the opioid receptor and is extremely related with the alleviation of human pain perception. Acetic acid-evoked writhing method, alternatively, is employed for the evaluation of the peripheral nociceptive activity. The constriction reaction of the abdomen entails the release of arachidonic acid from cellular phospholipids through cyclooxygenase and has usually been related to prostanoids, for instance, elevated levels of prostaglandins (PGE2 and PGF2 $\alpha$ ) in peritoneal fluids along with lipooxygenase (LOX) product. PGs stimulate abdominal constriction through triggering and sensitizing the peripheral chemo-sensitive nociceptors that are mainly accountable for resulting in inflamed pain [28].

This investigation suggested that $A$. pilosa methanolic extract possesses both peripheral and central antinociceptive attributes. Its peripheral antinociceptive activity has been deduced through its inhibitory effects on chemical (acetic acid) evoked nociceptive stimuli. At 400 $\mathrm{mg} / \mathrm{kg}(53.27 \%)$, the peripheral antinociceptive action of the extract on acetic acid-evoked pain has been observed to be similar to $5 \mathrm{mg} / \mathrm{kg}(69.67 \%)$ of diclofenac. The centrally acting protective effects of the extract have been confirmed by the hotplate as well as tail immersion tests results. The tail immersion test illustrated that the 


\section{Open Access Journal of Pharmaceutical Research}

biological activities were mediated through mu $(\mu)$ opioid receptors instead of kappa $(\kappa)$ and delta $(\delta)$ receptors [29].

In all analgesic models, the dose $(400 \mathrm{mg} / \mathrm{kg})$ was found to be more effective than the $(200 \mathrm{mg} / \mathrm{kg})$ dose. In the case of hot plate model, $400 \mathrm{mg} / \mathrm{kg}$ dose of the extract produced a rapid onset of action (Table 2) and the highest percentage protection (Figure 2) then $200 \mathrm{mg} / \mathrm{Kg}$ dose of the extract. The dose was also shown more effective than $200 \mathrm{mg} / \mathrm{kg}$ in reducing the writhing response (Figure 3). This possibly shows that $400 \mathrm{mg} / \mathrm{kg}$ dose of the extract is the optimum dose in producing both central and peripheral analgesic effect.

In the current research, Carrageenan utilized as a chemical agent to induce edema compared to formalin for the acute inflammation study due to the fact Carrageenan is found to be more trenchant in producing edema compared to formalin, showing a more trustworthy model for inflammation [30]. In the acute inflammation model, the plant extract of $A$. pilosa demonstrated the inhibitory effect on edema formation (Figure 4). This impact began from the $1 \mathrm{~h}$ and was retained until $3 \mathrm{~h}$. Its effect throughout the first phase implies that it activity entails inhibition associated with mediators like 5-HT and histamine. Diclofenac produced a more obvious edema inhibition in the late stage, which is in commitment with the undeniable fact that NSAIDs restricts inflammation considerably more in the second phase [3]. Production of arachidonic metabolites through the COX-2 enzyme is the significant factor liable for the late phase of Carrageenan evoked inflammation. The extract considerably inhibited paw edema in the second phase furthermore. These specify together revealed that the plant extract of $A$. pilosa might exert its activity furthermore through curbing COX and subsequent PG synthesis.

The preliminary phytochemical screening in our investigation revealed that methanol root extract of $A$. pilosa possibly consists of secondary metabolites such as flavonoids, alkaloids, tannins, phenols, steroids, fixed oils, fats, acid compounds, glycosides, amino acids, and proteins.

The anti-nociceptive effects of several plants have been gained via their flavonoid, terpenoids, tannin, phenol, steroid, alkaloid and saponin constituents [31-34]. Therefore, it may be stated that the antinociceptive activity of the plant extract of $A$. pilosa notices in Hot plate, tail immersion and acetic acid induced writhing models in the current research might be as a result of existence of saponins, flavonoids, steroids i.e., $\beta$-Sitosterol and Stigmasterol [35].

The anti-inflammatory action of several plants relates to the existence of saponins, flavonoids, terpenoids, triterpenes, glycosides and tannins [33,34,36-39]. Thus, it may be stated that the anti-inflammatory activity of the extract noticed in Carrageenan and formalin-induced paw edema models might be due to the occurrence of glycosides, flavonoids i.e., quercetin and rutin and steroids i.e., $\beta$-Sitosterol and Stigmasterol.

The co-existence of both anti-nociceptive and antiinflammatory effects that was noticed with this extract is well described for many NSAIDs. Therefore, it is fascinating that this extract behaved like NSAIDs in this research that correlates perfectly with the conventional application of the plant.

\section{Conclusion}

The antinociceptive and anti-inflammatory action of $A$. pilosa methanolic extract might be because to its secondary metabolites, that potentially include flavonoids, alkaloids, steroids i.e., $\beta$-Sitosterol and Stigmasterol and glycosides as well as rationalize the conventional utilization of this plant in folk medicine, being an antinociceptive and anti-inflammatory agent. But, further phytochemical, as well as biological tests, are recommended to determine the other active chemical constituents accountable for the antinoceceptive and antiinflammatory activities.

\section{References}

1. Shripad B, Abhijeet A, Inayat P, Nema N (2012) Analgesic and anti-inflammatory evaluation of Ficus microcarpa l. leaves extract. Asian J Pharm Clin Res 5(S4): 258-261.

2. Tasleem F, Azhar I, Ali SN, Perveen S, Mahmood ZA (2014) Analgesic and anti-inflammatory activities of Piper nigrum L. Asian Pac J Trop Med 7(S1): S461S468.

3. Ullah HA, Zaman S, Juhara F, Akter L, Tareq SM, et al. (2014) Evaluation of antinociceptive, in-vivo \& invitro anti-inflammatory activity of ethanolic extract of Curcuma zedoaria rhizome. BMC Complement and Altern Med 14: 346. 


\section{Open Access Journal of Pharmaceutical Research}

4. Bhandary M, Chandrashekar K, Kaveriappa K (1995) Medical ethnobotany of the siddis of Uttara Kannada district, Karnataka, India. J Ethnopharmacol 47(3): 149-158.

5. Marles RJ, Farnsworth NR (1995) Antidiabetic plants and their active constituents. Phytomedicine 2(2): 137-189.

6. Ghorbani A, Langenberger G, Feng L, Sauerborn J (2011) Ethnobotanical study of medicinal plants utilised by Hani ethnicity in Naban river watershed national nature reserve, Yunnan, China. J Ethnopharmacol 134(3): 651-667.

7. Gurib Fakim A, Sewraj M, Gueho J, Dulloo E (1993) Medicalethnobotany of some weeds of Mauritius and Rodrigues. J Ethnopharmacol 39(3): 175-185.

8. Galani V, Patel B, Patel N (2010) Argyreia speciosa (Linn. f.) sweet: A comprehensive review. Pharmaco Rev 4(8): 172-178.

9. Galani VJ, Patel BG (2011) Psychotropic activity of Argyreia speciosa roots in experimental animals. Ayu 32(3): 380-384.

10. Lalan BK, Hiray R, Ghongane B (2015) Evaluation of Analgesic and Anti-Inflammatory Activity of Extract of Holoptelea Integrifolia and Argyreia Speciosa in Animal Models. J clin diagn res 9(7): FF01-FF04.

11. Motawi TK, Hamed MA, Hashem RM, Shabana MH, Ahmed YR (2012) Protective and therapeutic effects of Argyreia speciosa against ethanol-induced gastric ulcer in rats. Z Naturforsch C 67(1-2): 47-57.

12. Yadav KS, Yadav NP, Rawat B, Rai VK, Shanker K, et al. (2014) An assessment of wound healing potential of Argyreia speciosa leaves. The Scientific World Journal 2014: 1-6.

13. Ahmed D, Saeed R, Shakeel N, Fatima K, Arshad A (2015) Antimicrobial activities of methanolic extract of Carissa opaca roots and its fractions and compounds isolated from the most active ethyl acetate fraction. Asian Pacific Journal of Tropical Biomedicine 5(7): 541-545.

14. Alam F, Najum us Saqib Q (2015) Pharmacognostic standardization and preliminary phytochemical studies of Gaultheria trichophylla. Pharm Biol 53(12): 1711-1718.
15. Harborne JB (1973) Phytochemical methods; a guide to modern techniques of plant analysis [by] J.B. Harborne. London: Chapman \& Hall.

16. Khandelwal KR (2008) Practical pharmacognosy : techniques and experiments. Maharashtra: Niral Prakashan.

17. Raaman N (2006) Phytochemical techniques. Pitam Pura, New Delhi: New India Publishing Agency.

18. Rajput A, Rajput $T$ (2012) Isolation of stigmasterol and $\beta$-sitosterol from chloroform extract of leaves of Corchorus fascicularis Lam. International Journal of Biological Chemistry 6(4): 130-135.

19. Hamad M (2012) Isolation of rutin from Ruta graveolens (Rutaceae) cultivated in Iraq by precipitation and fractional solubilization. Pharmacie Globale 3(4): 1-3.

20. Wan C, Yu Y, Zhou S, Tian S, Cao S (2011) Isolation and identification of phenolic compounds from Gynura divaricata leaves. Pharmacogn Mag 7(26): 101-108.

21. Kiran PM, Raju AV, Rao BG (2012) Investigation of hepatoprotective activity of Cyathea gigantea (Wall. ex. Hook.) leaves against paracetamol-induced hepatotoxicity in rats. Asian Pac J Trop Biomed 2(5): 352-356.

22. Eddy NB, Leimbach D (1953) Synthetic analgesics. II. Dithienylbutenyl-and dithienylbutylamines. J Pharmacol Exp Ther107(3): 385-393.

23. Chakraborty R, Biplab D, Devanna N, Sen S (2012) Antiinflammatory, antinociceptive and antioxidant activities of Phyllanthus acidus L. extracts. Asian Pacific journal of tropical biomedicine S953-S961.

24. Saha S, Guria T, Singha T, Maity TK (2013) Evaluation of analgesic and anti-inflammatory activity of chloroform and methanol extracts of Centella asiatica Linn. ISRN Pharmacol 2013.

25. Akele B (2012) In vivo anti-inflammatory and antinociceptive activities of aerial part extracts of Zhenria scabra. Int J Pharm Ind Res 2(4): 479-484.

26. Bartley EJ, Fillingim RB (2013) Sex differences in pain: a brief review of clinical and experimental findings. Br J Anaesth 111(1): 52-58. 


\section{Open Access Journal of Pharmaceutical Research}

27. Vegeto E, Benedusi V, Maggi A (2008) Estrogen antiinflammatory activity in brain: a therapeutic opportunity for menopause and neurodegenerative diseases. Front Neuroendocrinol 29(4): 507-519.

28. Mali A, Bandawane D, Hivrale M (2013) Evaluation of Anti-inflammatory and Analgesic Activity of Methanolic Extract of Cassia auriculata Leaves.

29. Schmauss C, Yaksh T (1984) In vivo studies on spinal receptor systems mediating antinociception. 11. Pharmacological profiles suggesting a differential associ-ii on of mu, delta and kappa receptors with visceral chemical and cutaneous thermal stimuli in the rat. J Pharmacol Exp Ther 228(1): 1-12.

30. Mohan M, Gulecha V, Aurangabadkar V, Balaraman R, Austin A, et al. (2009) Analgesic and antiinflammatory activity of a polyherbal formulation (PHFAROGH). Oriental Pharmacy and Experimental Medicine 9: 232-237.

31. Das SC, Bhadra S, Roy S (2012) Analgesic and antiinflammatory activities of ethanolic root extract of Swertia chirata (Gentianaceae). JJBS 5(1): 31-36.

32. Shaheen N, Ahmed S, Azhar I, Hasan MM (2013) Analgesic, anti-inflammatory and antiemetic activities of Cleome scaposa DC. Phytopharmacology 4(1): 106113.

33. Hernández Ortega $\mathrm{M}$, Ortiz Moreno A, Hernández Navarro MD, Chamorro Cevallos G, Dorantes Alvarez L, et al. (2012) Antioxidant, antinociceptive, and antiinflammatory effects of carotenoids extracted from dried pepper (Capsicum annuum L.). J Biomed Biotechnol 2012.
34. Tamil Jothi E, Vimala Devi G, Krishna VA, Suba V (2013) Analgesic, Anti-Inflammatory And Anti-Ulcer Activity Of Ethanol And Ethyl Acetate Extracts Of Tecomaria Capensis Leaves. International Journal of Research in Ayurveda \& Pharmacy 4(3 ): 430.

35. Gupta M, Nath R, Srivastava N, Shanker K, Kishor K, et al. (1980) Anti-inflammatory and antipyretic activities of $\beta$-sitosterol. Planta medica 39(06): 157 163.

36. Galati E, Monforte M, Kirjavainen S, Forestieri A, Trovato A, et al. (1994) Biological effects of hesperidin, a citrus flavonoid.(Note I): antiinflammatory and analgesic activity. Farmaco 40(11): 709-712.

37. Ku CM, Lin JY (2013) Anti-inflammatory effects of 27 selected terpenoid compounds tested through modulating Th1/Th2 cytokine secretion profiles using murine primary splenocytes. Food chemistry 141(2): 1104-1113.

38. Wu CR, Hseu YC, Lien JC, Lin LW, Lin YT, et al. (2010) Triterpenoid Contents and Anti-Inflammatory Properties of the Methanol Extracts of Ligustrum Species Leaves. Molecules 16(1): 1-15.

39. Bucar F, Knauder E, Schubert Zsilavecz M (1998) Studies on the antiinflammatory principle of Mentzelia chilensis. Phytotherapy Research 12(4): 275-278. 